\title{
ARTICLES
}

\section{CHICANA/LATINA UNDERGRADUATE CULTURAL CAPITAL: SURVIVING AND THRIVING IN HIGHER EDUCATION}

\author{
Maricela DeMirjyn \\ Colorado State University
}

Historian Vicki Ruiz mentions in her works the importance incorporating Chicana, Mexicana and Latina narratives into the academy, specifically in fields where our voices are marginalized (Meyer 2008, 23). This essay seeks to create a conversation regarding what constitutes Chicana/Latina cultural capital in relation to academic achievement by using the educational narratives of undergraduate students. Specifically, the text analyzes what forms of cultural capital Chicana/Latina undergraduates bring into higher education and, in essence, continue utilizing through their time within the university system. The primary goal of this work is to demonstrate that Chicanas/Latinas do have cultural capital that assists in academic success, as well as a sense of efficacy or agency within the system of higher education. As such, various subcategories of cultural capital are explored through the life stories of Chicanas/Latinas "surviving the system" of higher education. Through this analysis, the forms of cultural capital are refined as strategies used by Chicanas/Latinas to "manage, handle, carry out and respond" to their university experiences (Strauss and Corbin 1990, 101). For the purposes of this work, the identifier of Latina is used to be inclusive of the participants who self label as Mexicana, Mexican, Mexican-American or Latina, as all of the women are of Mexican descent and only half use the label Chicana.

Statistically it has been repeatedly demonstrated that Chicanas/Latinas share some of the lowest percentage rates of graduation in higher education at every level, from bachelor's degree on through doctoral degrees. Women of Mexican origin who are typically cited as "success stories" are often displayed as sell-outs, or vendidas, to their home/ethnic communities. The educational narratives embodied within this study demonstrate that there are other ways of "surviving the system" and keeping an ethnic identity as Chicanas/Latinas intact. Thus, this study represents what Mohanty (1994) refers to as a "collective voice" (153) regarding the educational experiences of Chicanas/Latinas pursuing their degrees in higher education. This collective voice is what Darder (1995) 
signifies as representing a cultural consciousness "grounded in collective memories of historical events, language, social traditions, and community life" (6). And, in part, this collective voice, grounded in a collective consciousness, displays a necessary critical reflexivity as a first step towards taking action in promoting educational equity (Hesford 1999).

The two research questions governing this study are as follows:

- How do Chicanas/Latinas perceive the campus climate as women of color?

- What forms of social/cultural capital are important for Chicanas/ Latinas in their own words?

Previous research acting as theoretical and conceptual guides for this work include studies relating to researcher identity and support networks identified as social/cultural capital within the Mexican American community.

Providing supporting evidence for what develops as Chicana/Latina student-oriented cultural capital in this study are two essential research works regarding Chicanas and education by Segura (1993) and Gándara (1995). Briefly, Segura (1993) mentions the key need for assisting Chicano/Latino students in gaining access to information regarding admittance procedures at the university level. Correspondingly, this article describes how Chicanas/Latinas actively seek assistance from peers, tutors, teachers, etc. and form networks with individuals or groups having information on how to get into college, thereby creating their own cultural capital. Additionally, the work by Gándara (1995) observing the impact of mothers' support in the academic success of Chicanas lends validation to the present analysis of mothers representing a form of cultural capital used in "surviving the system" by Chicana/Latina students.

Regarding past work referencing forms of social/cultural capital assisting academic achievement for Mexican Americans, two key sources were instrumental to this study. The first source is a dissertation by Diaz (1998) addressing the process of social and academic integration of Latino college freshmen. Interviewing 11 Latino students, Diaz focuses on personal attributes, as well as prior schooling influences, prompting Latinos to select education as a mechanism for upward mobility. Serving as a second source is Stanton-Salazar's (2001) examining of support networks for U.S. Mexican youth involving school and kin, which addresses how individuals are situated within their own personal web. He states, "much of what determines whether our associates might possess the resources we need depends on our own social class and background" (xi). Stanton-Salazar discusses his own experiences and personal network as being somewhat of an enigma and attributes it to the following:

I was privileged: by my fair skin, by having an immigrant mother and family in Mexico, by having a Chicano 
mixed-race father who was steadily employed and had family ties to White folks in the suburbs, by being sentenced to Catholic school, by having a bicycle, by having blue eyes and by looking somewhat White-and by being treated well by strangers who assumed I was. (x)

Other research revolving around "community cultural wealth" includes the following six areas of defined capital: aspirational, linguistic, familial, social, navigational and resistant (Yosso 2005, 70). However, these identified forms of capital have been attributed to social capital produced by various communities of color, and as such, have not been specifically applied to the academic success of Chicanas/Latinas within higher education. Lastly, the research by Delgado Bernal (2006) on pedagogies of the home touches base on the concept of cultural capital being constructed from a household knowledge base situated in the communities of Chicanas/Latinas. She states, "Pedagogies of the home provide strategies of resistance that challenge the educational norms of higher education and the dominant perceptions held about Chicana students" (Delgado Bernal 2006, 113).

My own experiences, as a Chicana who has "survived" various stages in her educational trajectory, set the tone for this body of research, as well as written works showcasing the impact and importance of linking pedagogy with voice. Theoretical pieces, such as Borderlands/La Frontera by Gloria Anzaldúa (1987/1999), altered my life by increasing my awareness of what it politically signified to celebrate my culture and my ethnicity as a woman of Mexican descent.

By using life stories as a means of expressing "voice" for university women of Mexican descent, the Chicanas/Latinas participating in this study are able to narrate their own sense of ethnicity in conjunction with their lived educational realities. Additionally, it enables an understanding of how these women engage in active agency regarding their survival in a racialized system socially formatted to accommodate White males. These Chicanas/Latinas are the subjects of their own becoming. They are women of color who are not only maintaining their racial/ethnic identity while pursuing degrees in higher education, but they are also using their "ethnic selves" as a source of strength. As one Chicana interviewee candidly remarks:

It drives me to be more successful because the odds are always against you. I feel as a Chicana demographics are changing, but I try to think about it, like in the literature, like in the Mexican Revolution, the women who were soldiers, who were there and never acknowledged. That's inspired me to set an example, not just for me, but my community. - Alicia 


\section{Methodological Influences}

"How educational research is conducted significantly contributes to what and whose history, community, and knowledge is legitimated. A Chicana feminist epistemology addresses the failure of traditional research paradigms that have distorted or omitted the history and knowledge of Chicanas" (Delgado Bernal 1999, 316). These are Delgado Bernal's (1999) concluding remarks regarding the impact of using Chicana epistemology in educational research as a means of resistance. She sees two key factors in the use of untold Chicana histories-her own and the women she writes about, which she views as providing "endarkened" (Dillard, 1997, as cited in Delgado Bernal 1999, 301) perspectives in educational research.

From a researcher's perspective, Delgado Bernal (1999) implies that Chicana researchers employ cultural intuition and that mainstream educational scholarship fails to provide a paradigm to study the realities of Chicana students. She states that cultural intuition as demonstrated by Chicana researchers is equivalent to Strauss and Corbin's "theoretical sensitivity," defined as "a personal quality of the researcher based on the attribute of having the ability to give meaning to data" (as cited in Delgado Bernal 1999, 307). Therefore, an understanding of data results from not only the research process and previous literature, but also from one's personal experiences and community affiliations. Zavella (1997) likens this to Chicana feminist research's overall ability to "present more nuanced, fully contextualized" (57) of Chicana experiences and identities. "Chicana feminist epistemology goes beyond quantitative versus qualitative methods, and lies instead in the methodology employed and in whose experiences and realities are accepted as the foundation of knowledge" (Delgado Bernal 1999, 303).

Both Delgado Bernal (1999) and Zavella (1997) situate themselves as Chicana researchers whose ethnic identity directly impacts and influences their work. By disclosing common ethnic background and experiences, they position themselves as running parallel lives to their interviewees. For example, in Delgado Bernal's 1997 study of eight Chicana student activists (cited in Delgado Bernal, 1999), she shared her experiences of when she was also a student activist. Zavella (1997), in her work regarding Chicana cannery employees, states "I hoped that my brief disclosures about my own ethnic heritage would allow my informants to express their own sense of ethnicity" (49).

This work establishes a transformative methodology that encompasses aspects of social feminist research as means of promoting a social theory regarding the agency of Chicanas in higher education and retention. As a feminist researcher using a feminist methodology, I attempt to give voice and subjectivity to women as a means of de-centering tradi- 
tional male-oriented research that objectifies (Neuman 2000). As a Chicana feminist researcher, I transform the above mentioned methodology to be inclusive of race and class, as well as other embodiments of comparative mainstream difference and power relations, aside from gender.

As a result, this study encompasses a Chicana methodology addressing "both the position from which distinctively Chicana research questions might be asked and the political and ethical issues involved in the research process" (Delgado Bernal 1999, 303). Furthermore, by definition of a feminist researcher, I am neither objective nor detached, but rather interactive in my work-fusing both my personal and professional worlds (Neuman 2000). This methodologically fosters my relationships with my interviewees by engendering aspects of equality and agency in the research dynamics. Using a Chicana feminist methodology allows for humanistic, action-oriented research, as well as flexibility in crossing boundaries between research techniques and academic fields that are both critical and interpretive (Neuman 2000).

The research site for this qualitative work is located in California's Central Coast at a public university where approximately $16 \%$ of the undergraduate student population is Chicano/Latino (University of California 2004). Twelve on-campus open-formatted interviews were conducted in a private office, as well as in secluded outdoor areas on the university grounds, and each interview took place for approximately 2 hours. (See Appendix A.)

Participants were volunteers, mainly hearing about the research project either personally or by the snowball effect, whereas one participant would recommend another potential participant (Krathwohl 1997). Requests for volunteer participants were also made in person through classroom announcements in Sociology and Chicana/o Studies courses, specifically the Sociology undergraduate classes of "La Chicana" and "The Chicano Community" and the Chicana/o Studies introductory class on Chicana gender. Visits to Latina-identified campus organizations, such as Hermanas Unidas, were made in an attempt to recruit additional participant volunteers.

My interests as a researcher regarding Chicana experiences in higher education, as well as the stipulation for participants to be of Mexican descent and to have either junior or senior status, was explained at the onset of each announcement. I indicated that although I was interested in the experiences of all Latinas, as a researcher I had to narrow my group focus. I also explained that the reason I was looking for volunteers who were either juniors or seniors, or in some cases "seasonal seniors" as campus students' refer to fifth-year seniors, was because I wanted to hear about their educational experiences at the university level. 


\section{Personal Profiles - Participants}

Alicia. Alicia is the second eldest daughter in a family with four children. Her older sister started college at the community college level, but Alicia is the first to attend a 4-year university. She grew up in Northern California and is interested in pursuing a political career advocating for social justice issues of concern within the Latino community.

Sonia. Sonia was born and raised in Southern California. She is the eldest child and has four brothers and sisters ranging in age from 1 to 15 years. Her college experiences began at a state college, but she transferred into the UC system after her first year. Sonia plans to go on to graduate school and currently she is majoring in Sociology.

Lorenza. Lorenza is the elder of two daughters and is from Southern California. She relies primarily on her spirituality and faith in the Virgen of Guadalupe to guide her through life. Lorenza is engaged, but is waiting to finish her bachelor's degree before getting married. Her long-term goals include entering the field of education; as she states, "My thing is to teach other people."

Antonia. Antonia has four brothers and sisters and is the second child in the family. She began college as an art student and was the first in her family to start attending a 4-year university. Antonia jokingly makes reference to being born in Mexico as a way of saving her father money on her delivery. Her future plans entail participating in the Teach for America Program.

Roxana. Roxana is the eighth child out of nine brothers and sisters. After the death of her father, she began taking classes at the community college level. Roxana was encouraged to transfer to the local university by her older sister who served as her role model. She remembers at the age of 6 years visiting her sister, who attended the same university. She says that her father was upset that her sister moved out, but that "he got over it" and "even made a desk for her," which the family still owns 20 years later. Roxana's goal is to become a counselor.

Lydia. Lydia is the first person in her immediate and extended family to go to college. She is the fourth child and has two brothers and two sisters. Lydia was raised in Northern California by her mother, who is her main mentor. She is light-skinned and gets teased for talking surfer slang. Her major is Global Studies, and her desire is to become a social justice activist.

Elva. Elva is the third member in her family to attend this university; however, as the youngest child, there was pressure for her to not leave home. Born and raised in Central California, she found the university to be "really different from home" because home was "primarily Mexican." She is currently involved in bringing members of her high 
school to campus, and Elva plans to continue working with students after obtaining a teaching credential.

Esperanza. Esperanza is the youngest out of four sisters. She is from Southern California and is the fourth daughter to go to college. As all of her older sisters attended UC schools, Esperanza had previous experience visiting three campuses, including here, before leaving high school. She says she chose this campus because her parents attribute her eldest sister's lesbian identity as being caused by the university environment and they "would have a problem" with her attending the same college and, also, the other campus was too close to home. After graduating, Esperanza wishes to advance her studies at the master's degree level in education.

Cristina. Cristina is the eldest of four brothers and sisters and is from Central California. Her parents are from a small ranch in Mexico and she is the first one in her family to go straight to the university. This is a big accomplishment; as Cristina says, "We're talking about 15 uncles and aunts and their children" who live in the states. Her future plans include joining the Peace Corp and teaching Chicano literature at her old high school.

Monica. Monica is the middle daughter in a family with three sisters. Her older sister attended a UC campus and served as a role model by sharing her experiences. Currently, Monica serves a similar capacity for her younger sister and, as Monica states, "She knows that she has to go to school." Her aspirations include attending medical school and specializing in cardiovascular health, which is due to what she believes was the premature death of her grandfather.

Concha. Concha is the eldest of four children, and she primarily raised her younger brothers and sisters due to her mother's difficulties with mental health. She identifies as both a Chicana and as a Native American since her grandfather is "Indio-Yaqui." Concha, a fan of "Che" early on in high school and having been labeled as a "communist" by her father, is very politically active on campus and within her community. Her goal is to become a high school counselor.

Sofia. Sofia is the second eldest out of a family with four children. She identifies as Lebanese Chicana and was raised from a young age by her father and stepmother after the death of her mother in a car accident. The primary language spoken at Sofia's home is Spanish, although she does know some Arabic. She is close to her father's Lebanese family, as well as to her Mexican family members on her mother's side. Her future goals include activism and graduate studies. 


\section{Life Stories}

The use of life stories or narratives collaborates well with this project's philosophy of following a Chicana feminist epistemology/research by allowing the autonomous voicing of participants recounting their personal experiences. The authenticity of this work is revealed in its candidness and direct portrayal of these narrated lived realities by Chicana/ Latina undergraduates. As such, it "provides a detailed account of how those being studied feel about and understand events" (Neuman 2000, 171). Additionally, as a Chicana feminist researcher I adhere to an overall sense of validity as being displayed within truthful accounting of experience.

\section{Grounded Theory}

This research study begins with an interest in the roles that ethnic identity and social/cultural capital play in the success of Chicana/Latina university students. By applying grounded theory as a methodology, this work sets out to discover, develop, and provisionally verify via data theoretical principles pertaining to the above mentioned phenomenon (Strauss \& Corbin 1990). Grounded theory as a means of using Chicana/ Latina undergraduate educational narratives to build a theoretical relationship between social/cultural capital and ethnic identity, as well as agency, occurs during the collection and initial analysis of the data (Neuman 2000). Hence, as a methodological practice or approach, grounded theory evolves within the actual process of the research study. This coincides with the philosophical portrayal of this work as a transformative site for lived experience and Chicana feminist epistemology by maintaining research fluidity. Theorizing in this manner leads towards different ways of looking at previous data and assists in the formation of new connections and understandings.

\section{Phenomenology}

Also playing a methodological role in this work is phenomenology. Stewart and Mickunas (1974) state that phenomenology "insists upon openness to the full range of social reality" (129) and that it may be used to examine aspects of human life, such as education. In addressing values, goals, and meanings relating to Chicanas/Latinas experiences in higher education, this research specifically uses a Chicana phenomenological approach. Such an approach is based on a transformative notion combining Chicana ideology and awareness with traditionally employed phenomenological practices. Thus, it entails subjective interpretations and perceptions of the lived experiences shared within the stories by the participants that acknowledge Chicana consciousness as a way to identify key events, ideas, or themes within educational narrative data. Mar- 
tinez (2000) recognizes Chicana phenomenology as being not only descriptive but interpretive and critical of what she labels "social, discursive, historical, and cultural discriminations" (96).

\section{Chicana/Latina Undergraduate Cultural Capital}

As previously stated, this article addresses the forms of cultural capital brought to campus by Chicana/Latina undergraduates. An analysis regarding what constitutes Chicana/Latina capital as the participants enter the university system began by coding their educational narratives for conceptual categories. In a process similar to open coding, transcripts were reviewed by both the researcher and auditors for themes relating to capital assessed as supporting retention or continuing educational success.

The next step in the data analysis entailed creating domains by comparing and contrasting the various categories and themes making separations between forms of capital. During the second pass or axial coding of the educational narratives, three themes were developed, as well as their corresponding subthemes. Coded and labeled under the primary theme of mothers are the two subthemes of verbal support and role model. The second theme, high school outreach, houses the two subthemes of student organizations and academic programs. The third, social networks, contains five subthemes and includes advisors/counselors, peers, siblings, teachers, and tutors.

\section{Mothers}

Two subthemes developed regarding how the mothers of the Chicana/Latina interviewees serve as a source of cultural capital. The first subtheme, verbal support, consists of what the Chicana/Latinas narrated as their mothers' verbal influence towards their educational trajectory into higher education. The second subtheme, role model, in essence speaks to the participants' mothers as guiding them to do well in school by how they lived their lives.

Verbal Support. As demonstrated in past research, mothers are seen as impacting the academic success of their Chicana/Latina daughters regardless of their own educational levels. None of the mothers of the Chicanas/Latinas interviewed had a high school degree and most were educated in Mexico up to secondary school. The following accounts are examples of the participants' mothers supplying verbal support regarding education that are converted by the Chicana/Latina narrators into a source of cultural capital for assisting in their academic success.

Education is just really important to my mom. She was the one that was like, "Do you know what you're going to do? Do you know where you're going to college?" - Antonia 
I always received a lot of family support. My mother was especially involved with school; my father not so much because he had to work from 5 a.m. in the morning. The only thing they told me was "School is important. Finish school. Finish school." The only college we were exposed to in Orica was community college. That's when my mom would always tell me, "There's where you're going to go." - Cristina

The above excerpts make evident that the mothers of the Chicanas/Latinas in this study actively supplied a source of cultural capital by voicing "pro-school" messages to their daughters. In some cases, the mothers' lack of formal knowledge regarding the system of higher education limited the scope of what they were able to voice, but the underlying meaning of support for reaching beyond a high school degree is undeniable. These excerpts portray moments in the Chicana/Latinas educational narratives temporally located while the students were at high school age or younger.

Role model. The excerpts below include three samples using coding for the terms role model in conjunction with mom or mother.

My biggest role models in life in general are my grandmother and mom. Just because they, you know, I look up to them a lot. They've done so much. They've gone through so much. They share their stories with me all the time. I sit for hours with my grandmother and she tells me everything. They're my biggest role models, my biggest inspirations. - Elva

I'll start by talking about my mom since she's one of the main reasons why I'm here. Just growing up with her and seeing how she struggled as a single mother and her strong will. It's just inspired me to do more than she has, since I was small. She's always told me "I'm not an educated woman, but you can be and you have the opportunity to be and I came over here to give you the opportunity." So my mom came here from Mexico. She has crossed the border illegally many times. -Lydia

Although mothers most definitely play a prominent role in terms of Chicana/Latina undergraduate cultural capital, in a few circumstances either a grandmother or an aunt played a similar role. In these cases, these women, seen as family elders, provided additional support for the participant or were the only source of support in the cases where the mother was inaccessible to the student. In two narratives, the mothers were unavailable due to death or mental health problems. However, both women 
were still briefly mentioned in the context of the narratives. It is also important to note that on occasion the Chicana/Latina participants made reference to their "parents" or fathers as supplying educational support.

My senior year in high school is when I realized that mom and dad didn't come from Mexico so I could just throw my life away and take everything for granted. It wasn't an easy transition for them; they left their family behind. I just realized it. I have so many more opportunities here than they did over there. So, I went to Coastal College and went through their transfer program and went to UC last year. - Roxana.

\section{High School Outreach}

The second thematic category focuses on two components of outreach occurring at the high school level. The first component is coded under the subtheme student organizations and the second component is categorized under the subtheme of academic programs. The excerpts coded for the overarching theme of high school outreach specifically address instances in the Chicana/Latina educational narratives when groups and not individuals were mentioned as providing access to either information regarding college or promoting college accessibility.

Student organizations. As a subtheme, student organizations includes any coded references to high school groups in which the Chicana/ Latina narrators were members. It specifically addresses program involvement that assisted in increasing the Chicanas/Latinas' cultural capital by increasing their levels of awareness regarding college matters. The following passages are indications of coded data regarding frequent involvement in Latina/o student groups, such as MEChA (Movimiento Estudiantil Chicano de Aztlan), although from time to time references to sport clubs or theatre were found in the narratives.

I also had another Spanish teacher who was always helping me, got me involved with MEChA at school and later I got involved with being President of the Spanish Club. So there were always people, there were always a lot of role models. A lot of them were Latinos who were helping me and trying to tell me what was happening at school, where to go for certain information.

- Cristina

We actually started off [MEChA], my best friend who is here at UC, was the president so the UCX [University of California, anonymous campus] folks came over and said, "We're here to help. We're the most active chapter in Southern California. We'll host a meeting." They had their own workshops like UCX Raza workshops. Like 
even last year I went back and saw the workshop that we started where high school students teach each other about activism and how to go about, you know, in your high school and see all the discrimination and how to take steps to change that. So we had our own workshop on that, so I think it was thanks to the guidance from the UCX students who were there with their outreach program every day, who would really encourage us to read this, or they would come into our Chicano Studies class, "you're reading this go to this event. There's this person speaking" and you know just a lot of inspiring words and their moral support. And I think that's when we really discovered what it meant, the political and everything else that comes with being Chicana. I have a whole philosophy of "Chicana no nace se hace." You know, "You aren't born a Chicana, you become one." So I think it was probably junior and senior year at our high school, when I was like "wow. This is me. This is something I want to be part of." - Lorenza

I was really active in high school. So my sophomore year I got involved in MEChA and I really got involved with that and doing different cultural events. Like Cesar Chavez and honoring him. I joined ASB [Associated Student Body], Link Crew; it was to help mentor freshman and Spanish Club. I've learned to balance my time. - Monica

Overall, the students groups, such as MEChA, created spaces for the Chicana/Latina participants to establish their footing as marginalized students within our educational system. By interacting with other students, the interviewees were able to acquire assets, including time management and reading materials, which acted as stepping stones for their future academic success.

Academic programs. Academic programs, as the second subtheme of high school outreach, relates to all the excerpts coded in the Chicana/ Latina narratives indicating a particular program oriented towards assisting their academic achievement. These programs include references to experiences during the participants' high school years, as well as summer bridge programs while transitioning into college.

I went to Summer Discovery Program and it was for high school students as a precollegiate experience and I came here and I stayed at Santa Clarita [student dorm] for a month and a half, I took that first summer session 
as a student. So I took Chicano $1 \mathrm{~A}$ and Soc 2 and I found out that I loved being on my own.

- Cristina

And then I got involved with this class, it's called AVID [Advancement Via Individual Determination]. And it's a program to get underrepresented students in college and so it helped a lot. I actually went for my first college campus as a field trip and they showed me what I had to do, the entrance essay that I didn't know anything about. - Lydia

I came to STEP [Striving Toward Educational Possibilities], a program funded by EOP [Educational Opportunity Program]. It's a 2-week program and that was really helpful. I think that really gives us a head start. We know the campus, we get to know the library, all the basics we need, we enroll in classes, we get our IDs, we get to know the bookstore. It's an awesome program and if it wasn't for STEP, I probably would have been lost in the first week of school. - Elva

All of the above mentioned programs provided a source for students to gain a systemic understanding of the necessary steps for not only continuing onto the university level, but also for succeeding within academe.

\section{Social Networks}

The final theme of this analysis delves into the use and construction of social networks by Chicana/Latina students as a means of acquiring information pertaining to entrance into higher education. All of the women interviewed identify as "first-generation" college students. The types of alliances were separated categorically into five subthemes. These subthemes include advisors/counselors, peers, siblings, teachers, and tutors.

Advisors/counselors. The Chicana/Latina undergraduates in this study repeatedly mention within their narratives specific junior high and high school counselors, or academic advisors in a club or group in which the narrators were members. The gender or race/ethnicity of these individuals was frequently female and non-White, however, there were a few exceptions, such as in the case of "Mr. Lopez." The following excerpts represent evidence of advisors/counselors as a form of Chicana/Latina cultural capital used as a means of bridging their way into higher education. 
One of the counselors at high school she had mentioned that she had majored in sociology and said "Why don't you take one of those classes and see if you like it and major in that?"

- Roxana

In the 7th or 8th grade some teacher, I think her name is Ms. Montoya, recommended me for this program called AVID and since then I remember Mr. Lopez who was the person in charge of that, he was the one who totally changed my view on everything. I'm going to probably thank him for life because he was the one that talked to me about college. He took me on a field trip with a couple of other students to UC, and during that time I was probably like a $\mathrm{C}$ or $\mathrm{D}$ student, so for me, my goal was to finish high school and get a job and that was it.

Mr. Lopez was the first one to tell me there were scholarships and financial aide and I was like "Damn, they help poor people?" So since then . . . my grades raised and he would tell us how to do notes and how to organize our binder, and also once we were sent to high school he was "College Prep, College Prep and never be afraid to ask" because he said "Nobody is going to come to you and tell you that this is what you need for school. You have to ask." I remember Mr. Lopez told me "You know, just because you enter the university, it doesn't mean that you've made it. Once you show me that you got your bachelor's degree, that's when you know you made it and you can go further on." - Cristina

I also had a counselor really push me to come here. $\mathrm{He}$ came here too and he was really supportive. The director in the Upward Bound Program was always really supportive in taking us to different schools. So, I always had outside support and resources. - Monica

Typically, most of the advisors or counselors who were mentioned within the educational narratives were voiced as having shared a similar upbringing or cultural background to the participants. Conclusively, the similarities shared between both groups may have assisted in the creation of a trusting or safe space in terms of the students opening up with their future plans. 
Peers. This subtheme includes passages by the Chicana/Latina undergraduates coded for references to high school friends or associates who were influential in the decisions pertaining to higher education.

Friends, I've had a lot of friends whether they're older or the same age as me, just because I see them and I see their desire or strength to keep going, although they've had so many obstacles throughout the way to, to maybe stop them or make it difficult for them to continue. Esperanza

One of my best friends, Nan, she was very involved in school activities and Future Leaders of America, CSF [California Scholarship Federation], and she was the one who was always telling me "You have to be in this program it helps you for this." Because she had relatives that had gone through the process so she was always helping me. ... It was important for me to do community service. By getting involved ... I was doing a lot of networking, especially with mujeres helping me out and everything. So it's really just great to know that maybe even though I didn't get a lot of mentor from my cousins or aunts, I know that I had a lot of help from my immediate, closest friends. - Cristina

I came in as a Chicano Studies major because I always have known I wanted to do that. My friends are all majors at UCX and I was like "oh their books are interesting" and I would sneak into their classes. So, I've always known that I wanted to be Chicana/Chicano Studies. Lorenza

Friendship networks have continually been show to be a source of support for individuals. In the case of this study, the majority of the friendship networks of the interviewees were identified as being of Latina/o descent. This may explain why the peers were viewed as providing examples of how surviving and thriving within the university system is possible.

SibLINGS. For this subtheme, the Chicana/Latina educational narratives were coded for both male and female siblings; however, most cases coded as a form of cultural capital are excerpts referencing older sisters. The following passages provide an example of how the participants' siblings assisted in transferring cultural capital regarding higher education.

Since my sisters were older than me and they went to UC campuses, I had visited UCY, UCZ, and here. So I 
had visited all three campuses when I was younger and my sisters would always be on me about my grades, college applications, "When are you going to do this?" SATs, and all this stuff. AP [Advance Placement] classes, "Take as many AP classes as you can." though not many were offered at my high school. So they would help me a lot with that. - Esperanza

And seeing my sister, she's older. She paved the way. She had joined Upward Bound and that's what got her into college and then I joined it too. And that gave me the experience of living in the dorms, taking classes, and doing things on my own. - Monica

When I was in junior high, my oldest brother graduated from high school and he went to UC. So that was the biggest jump that our family had done. He was the first person in the family to go to college and because of him came all the expectations for the rest of us because he went to college and it's like "Okay, now everyone else." He would always call me, always checking up on me. "How are you doing in school? What are you grades like?" All the time, he would just really push me and that's really good, really good and now I'm here. And then so my sister, who is a year younger than him, when she graduated from high school, she also came to UC. So, it kind of started this, you known.

- Elva

Although the majority of the participants with siblings who motivated them to go onto college were sisters, those who did have brothers either in the university system or as college graduates were equally supported despite gender differences. This would seemingly go against the stereotypical gender norms attributed to Latina/o households.

Teachers. The subtheme of teachers provides a space for the coding of excerpts of the Chicana/Latina educational narratives for instructors identified by the narrators as key figures in their educational trajectories. The following excerpts provide an example of how the Chicana/Latina participants center their social networks with past teachers as undergraduate cultural capital.

My English teacher in junior high and two Spanish teachers in high school; they both were really encouraging and helped me out with college applications and personal statement. - Monica 
One of my AVID teachers who actually was White, was one of the people who helped me out the most. She was White, but she just lived a very different experience. Her dad didn't support her financially at all. She was a teenage mother, and was on welfare and went through college raising her kids, so I saw my mom in her somehow. She inspired me to go and not to go to community college. - Lydia

I remember in 9th grade, the first class I ever went to was first period English. There was this teacher who, I couldn't figure out what ethnicity/race she was. She turned out to be Italian. . . . the first thing she said was "If you're going to take something from my class, it's that you really want to go to college." College? I mean half of the people there just looked at each other and laughed. You know, like "College, yeah right! We're not going to go to college" and what not. But throughout the year she was, every assignment had to do with college regardless of what the assignment was, you knew she was going to be talking about college. "In college, if this interests you, you can go ahead and study it further in college and do research." Research? "What the hell is that?" You know, research seemed like such a foreign word. First I wasn't sure what research really was, but she said, "That's when you can really dig deep into your passion." I thought, "Crazy, she's just talking nonsense, none of us are going to college." Lo and behold, the last day of class she's like "What did I tell you? In my class there wasn't going to be a day that you didn't think about college." So, I think she has probably been the first person to talk to me about college. She's probably the reason why I am here. You know, she was the one to tell me, "Can I see your schedule? You should be in Honor's classes. Okay, we're going to meet with your counselors." - Lorenza

An important detail to note from these passages is that teachers, regardless of their ethnic or racial backgrounds, played key roles in verbally motivating the Chicana/Latina narrators to pursue their educations at the university level.

Tutors. This subtheme as a category encompasses data coded using the word "tutor" as well as "mentor" in the educational narratives of the Chicana/Latina participants. Although in many cases direct references to 
names were not provided by the Chicana/Latina undergraduates, attention was paid in the coding process to the specific mentioning of adult individuals noted as assisting the narrator who were not identified as either counselors or teachers. The following excerpts demonstrate tutors/ mentors at the high school level as a form of pre-campus Chicana/Latina cultural capital.

Yeah, Ms. Ramirez, she started a program called Project College Bound and she took mostly minority, low-income students. I was one of those students and we'd have these workshops and I had a mentor. She was really cool. She was the first White woman I saw take an interest in minorities. And when I first met her, I thought "Oh great." You know? I had bad experiences with my teachers at Santa Rosita High and so I was kind of like "Okay, whatever." But after the program was over and I had graduated from high school, . . . we were the only ones that kept in touch. All my other friends and their mentors never kept in touch and she'd come over to my birthday party, she came to my dad's funeral. Stuff like that. It meant so much to me and she would take me to college fairs, like Coastal College. She was just very supportive and I just thought that was great. - Roxana

Luckily I went to the Care Center one day and there was a guy from Cal State and he was talking about Cal State and how he could help me with the application process. So I took interest and I got help from him. He helped me out, filling out the application and he even took me to Cal State to turn in the paperwork because I applied in January, so I applied late. He really was a help. - Sonia

One of the UC students that would come and do the tutoring at my high school. She was also just in the same place I'm at, first generation, what a lot of Chicanas are, first generation, low-income background and she was kind of the first one. I never really opened myself up to anyone. I would go in and get tutored and ... she'd help me with my homework, but she actually took time to really hear my family issues and say "maybe you should try this out. Or sometimes culturally this is what our parents have been taught and maybe it's different from what we might think" and how do deal with a lot of, just the generational, the, my beliefs and my parents that are contradicting at times. She's the one who taught me how 
to deal a lot with that because my parents, my sister, we're such a little family, that we're used to being around each other." - Lorenza

In most cases, by having a mentor at the high school level, the Chicana/ Latina participants were able to gain the needed "know how" for taking the next steps in continuing on with their educational careers. Tutoring by college students who self-identified as Chicana or Latina also provided an avenue by which the Chicanas/Latinas in this study were able to obtain the necessary information, as well as inspiration.

As demonstrated by this study, there is potential for Chicanas/Latinas to not only survive but thrive in the system of higher education. Analysis of the narrative reflections by the participants shows the complexity of creating and using cultural capital as strategies for academic success. The three main thematic categories of mothers, high school organizations and social networks support identifiable sources of Chicana/ Latina capital. Additionally, the analysis reveals how cultural capital can be developed and is "evolving in nature" allowing for longitudinal studies "in terms of sequences, or in terms of movement, or change over time" (Strauss \& Corbin 1990, 104).

Future discussions regarding Chicana/Latina cultural capital involve looking at how this capital remains fluid in terms of use and construction. This entails investigating the ways in which Chicana/Latina undergraduates continually use specific forms of previously established cultural capital, as well as create new forms while attending college for both themselves and future generations of Chicana/Latina students. Specifically, engaging research on how networks are not only created, but maintained, will assist in understanding the impact on both recruitment and retention of Chicanas/Latinas in the university system.

This work challenges an assimilationist model as the only model for academic success at the university level. Analysis of the narrative reflections by Chicana/Latina university students shows a complexity of strategies, including social networking among family and friends, creation of "safe space," and use of ethnic group membership and identification as a means of graduating with college degrees. The next project for publication will entail a detailed description of how forms of Chicana/Latina cultural capital are carried throughout the college careers of women of Mexican descent as students, as well as how additional forms of capital are constructed in the process of surviving and thriving.

\section{REFERENCES}

Anzaldúa, Gloria, Borderlands/La Frontera: The New Mestiza 2nd edition. San Francisco: Aunt Lute Books, 1999. 
Darder, Antonia, "The politics of biculturalism: culture and difference in the formation of "warriors for gringostroika and the new mestizas'," in Culture and Difference: Critical Perspectives on the Bicultural Experience in the United States, ed. Antonia Darder (Westport: Bergin and Garvey, 1995). 1-20.

Delgado Bernal, Dolores, "Using a Chicana feminist epistemology in educational research," in Learning as a Political Act, ed. José A. Segarra and Ricardo Dobles (Cambridge: President and Fellows of Harvard College, 1999). 301-325.

Delgado Bernal, Dolores, "Learning and living pedagogies of the home: the mestiza consciousness of Chicana students," in Chicana/Latina Education in Everyday Life: Feminista Perspectives on Pedagogy and Epistemology, ed. Dolores Delgado Bernal, et.al. (Albany: State University of New York Press, 2006). 113-132.

Diaz, Jessica C., "Process of Social and Academic Integration Among Latino College Freshman." (Ph.D. diss., University of California, Santa Barbara, 1998).

Hesford, Wendy, Framing Identites: Autobiography and the Politics of Pedagogy. Minneapolis: University of Minnesota Press, 1999.

Krathwohl, David, Methods of Educational \& Social Science Research: An Integrated Approach 2nd edition. New York: Addison Wesley Longman, 1997.

Martinez, Jacqueline M., Phenomenology of Chicana Experience and Identity: Communication and Transformation in Praxis. Lanham: Rowman \& Littlefield, 2000

Meyer, Leisa D., “' Ongoing Missionary Labor’: Building, maintaining, and expanding Chicana studies/history an interview with Vicki L. Ruiz," Feminist Studies 34.1/2 Spring/Summer (2008): 23-45.

Mohanty, Chandra, "On race and voice: challenges for liberal education in the 1990s," in Between Borders: Pedagogy and the Politics of Cultural Studies, ed. Henry Giroux and Peter McLaren (New York: Routledge Press, 1994). 145-166.

Neuman, William L., Social Research Methods: Qualitative and Quantitative Approaches 4th edition. Needham Heights: A Pearson Education Company, 2000.

Stanton-Salazar, Ricardo D., Manufacturing Hope and Despair: The School and Kin Support Networks of U.S.-Mexican Youth. New York: Teachers College Press, 2001. 
Stewart, David and Algis Mickunas, Exploring Phenomenology: A Guide to the Field and its Literature. Chicago: American Library Association, 1974.

Strauss, Anselm L. and Juliet M. Corbin, Basics of Qualitative Research: Grounded Theory Procedures and Techniques. Newbury Park: Sage, 1990. University of California, Student Handbook, September 26, 2004, http://kiosk.ucsb.edu/Diversity/whatdoesucsblooklike asp ?page $=$ diversity \& subpage $=$ whatdoesucsblooklike

Yosso, Tara, "Whose Culture has Capital? A Critical Race Theory Discussion of Community Wealth," Race Ethnicity and Education, 8.1. (2005): 69-91.

Zavella, Patricia, "Feminist insider dilemmas: constructing ethnic identity with "Chicana" informant," in Situated Lives: Gender and Culture in Everyday Life, ed. Louise Lamphere, Helena Ragoné, and Patricia Zavella (New York: Routledge Press, 1997). 42-61. 


\section{APPENDIX A \\ Interview Questions}

\section{General - Warm up}

Describe your educational experiences.

What are your feelings or perspectives about college?

Describe your college experiences.

\section{Family/Mentors}

What is your family background?

How did/does your family support your education? Which family members played significant roles $\&$ in what ways?

Describe any mentors you have had, both family and non-family.

\section{Racial/Ethnic Identity}

How would you describe yourself?

When asked the question, "What are you?" how do you respond?

How has your ethnicity or race influenced your education?

As a student, have you ever been accused of "acting White?" If so, please give an example.

How, if ever, has your ethnic identity been questioned?

Do you see yourself as being bicultural or multicultural person? If so, in what ways?

What stereotypes, if any, have you had to face?

How has your ethnic identity impacted your educational experiences?

\section{Campus Compatibility \& Climate}

How do you view your college environment?

We think of university settings as being sterile or impersonal. What have your experiences been?

Do you have a sense of belonging on campus?

How comfortable have you been while going to college?

\section{Academic Identity \& Adaptability}

What makes you a college student?

When you think of a good college student, what qualities come to mind?

Does your ethnic identity conflict in any way with your academic identity? If so, in what ways?

What makes you adaptable to college life? How have you adapted to being a college student? 
How prepared were you for leaving home? What did you do to make the transition easier?

How do you handle stressful times? Or how have you handled past situations related to school that were stressful?

\section{Self-Reflection \& Expectations}

Discuss why you are going to college.

Describe your overall view regarding your educational career to date.

Do you see yourself as having potential to succeed? If so, in what ways?

What are your next steps after finishing your undergraduate degree? 